\title{
PENGEMBANGAN MODUL FISIKA BERBASIS KARAKTER DENGAN PENDEKATAN STM PADA POKOK BAHASAN KINEMATIKA GERAK LURUS UNTUK MENINGKATKAN KUALITAS PEMBELAJARAN FISIKA SISWA KELAS X MADRASAH ALIYAH DARUL MA'ARIF NUMBAY JAYAPURA
}

\author{
Irawaty $^{1),}$ Yusuf Bungkang ${ }^{2)}$ \\ ${ }^{1}$ Alumni Program Studi Magister Pendidikan IPA Universitas Cenderawasih \\ ${ }^{2}$ Dosen Program Studi Magister Pendidikan IPA Universitas Cenderawasih
}

\begin{abstract}
Absract This research and development have as a purpose to produce teaching material in the form of physics module based character with science technology community approach. The implementation stage includes Define, Design, Develope, and Disseminate. Products are developed and tested its effectives. Techniques data collection include sheet questionnoiere responponses, cognitive test and test result of learning. In this research, held twice test that is given the initial test (pre test), final test (post test), and the test result of learning. Techniques data analysis include validation test, normality test, homogenity, score gain analysis and hypothesis testing. This research result is guite good. Before application learning, the ability of the students learning 51,46 and then increased to 77,53 with a score gain analysis and from the result of hypothesis testing with $\mathrm{F}_{\mathrm{Hit}} 13,090>4,17 \mathrm{~F}_{\text {talbe }}$ and significance count $0,01<$ 0,05 table and significance which means that in the learning process by using physics module based character with science technology community approach able to increase the physics learning quality on the subject matter of physics kinematics rectilinear motion for students class X in Madrasah Aliyah Darul Ma'arif Numbay Jayapura.
\end{abstract}

Keywords: module physics, character, science technology community, kinematics rectilinear Motion

Abstrak. Penelitian Research and Development ini bertujuan untuk menghasilkan bahan ajar berupa modul fisika berbasis karakter dengan pendekatan Sains Teknologi Masyarakat (STM). Tahap pelaksanaan meliputi Define (pendefinisian), Design (Perancanaan), Develop ( Pengembangan), dan Disseminate (penyebaran). Teknik pengumpulan data meliputi validasi ahli materi dan ahli media pembelajaran, respon siswa, tes kognitif dan tes hasil belajar. Dalam penelitian ini, diadakan dua kali tes kognitif (pretest dan Posttes), selain itu data juga diambil dari tes hasil belajar. Teknik analisis data meliputi Uji Validasi, Uji Normalitas, Uji Homogenitas, Analis gain score ternormalisasi, dan uji hipotesis dengan menggunakan one way anova. Hasil penelitian ini tergolong baik. Sebelum diterapkannya pembelajaran tingkat kemampuan siswa mencapai 51.46 kemudian meningkat menjadi 77,53 dengan analisis gain score ternormalisasi. Hasil uji hipotesis dengan menggunakan one way anova didapat $\mathrm{F}_{\text {hit }}$ $(13,090)>\mathrm{T}_{\text {tabel }}(4,17)$ dan signifikasi hitung $0,01<0,05$ signifikansi tabel yang berarti bahwa dalam proses pembelajaran dengan menggunakan modul fisika berbasis karakter dengan pendekatan STM mampu meningkatkan kualitas pembelajaran fisika pada pokok 
bahasan kinematika gerak lurus bagi siswa kelas X di Madrasah Aliyah Darul Ma'arif Numbay Jayapura.

Kata Kunci: Modul Fisika, Karakter, Sains Teknologi Masyarakat, Kinematika Gerak Lurus

\section{PENDAHULUAN}

Kurikulum pembelajaran menuntut guru untuk mampu mengembangkan sumber belajar sendiri. Salah satu sumber belajar menurut Departemen Pendidikan Nasional adalah bahan ajar. Bahan ajar yang dikembangkan dapat berupa bahan cetak, film, audio tape, video tape, peta, globe, carta atau kombinasi keduanya. Diharapkan bahan ajar yang dikembangkan dapat menjadi sarana belajar untuk mempermudah siswa dalam menangkap materi pembelajaran yang diajarkan (Suprawoto, 2009).

Modul merupakan salah satu bahan ajar yang biasa digunakan untuk pegangan bagi siswa. Modul penting bagi terselenggaranya belajar mandiri bagi peserta didik itu sendiri, Modul juga dapat di integrasikan dengan pendidikan karakter. Oleh Karena itu pengembangan modul ini yang dikembangkan dalam pembelajaran fisika hendaknya dapat mendukung tercapainya tujuan pendidikan karakter.

Perkembangan ilmu pengetahuan dan teknologi dapat dihubungkan dengan menggunakan pendekatan STM. Pendekatan STM dapat mengembangkan kemampuan efektif dan kognitif melalui soal-soal latihan serta psikomotor siswa melalui kegiatan ilmiah. Pembelajaran menggunakan pendekatan STM dapat mengembangkan kemampuan kognitif, afektif dan psikomotor siswa dengan harapan dapat diaplikasikan dalam kehidupan sehari-hari (Poedjiadi, 2010). Penerapan pendekatan STM sebagai kerangka dasar dalam pembuatan modul diharapkan dapat mempermudah penyampaian materi fisika kepada siswa.

Penyampaian materi fisika melihat dari segi kemajuan sains dan perkembangan teknologi, tetapi perlu dilengkapi dengan moralitas dan akhlak yang baik. Faktor utama yang diperlukan untuk melengkapi kemajuan sains dan teknologi adalah moralitas manusia (Poedjiadi, 2010). Melalui penanaman pendidikan karakter diharapkan siswa mampu menilai dampak positif dan negatif kemajuan teknologi.

Berdasarkan hasil observasi di kelas X Madrasah Aliyah Darul Ma'arif Numbay Jayapura menunjukkan buku ajar yang digunakan dalam proses pembelajaran fisika belum memuat nilainilai karakter. Oleh sebab itu, media untuk melatih karakter yang ada dalam diri siswa belum tersedia. Selain itu hasil belajar fisika siswa tidak mencapai 
KKM, hal ini dikarenakan siswa tidak mempunyai bahan belajar mandiri. Bertolak dari permasalahan tersebut, maka diperlukan suatu bahan ajar fisika yang terintegrasi nilai-nilai karakter sehingga nantinya dapat meningkatkan perilaku berkarakter siswa juga dapat meningkatkan hasil belajar siswa. Deangan demikian pengembaangan karakter siswa, terutama terkait dengan nilai, sikap, dan kebiasaan positif dalam berpikir, bertindak, dan berinteraksi dengan Tuhan, alam, maupun orang lain diperlukan. Pengintegrasian nilai-nilai karakter ke dalam materi fisika dapat dilakukan dengan cara menggali nilainilai karakter yang terdapat dalam materi fisika tersebut. Dengan menggali nilainilai karakter dari materi fisika diharapkan pembelajaran yang dilaksanakan lebih bermakna pada kehidupan siswa sehingga mampu mengembangkan seluruh potensi yang terdapat dalam diri siswa secara optimal, baik potensi kognitif, afektif, dan psikomotor.

Salah satu materi fisika yang berkaitan dengan kehidupan sehari-hari adalah kinematika gerak lurus. Didalam materi kinematika gerak lurus menjelaskan perpidahan benda tanpa melihat gaya yang bekerja pada suatu benda itu sehingga menyebabkan benda berpindah. Nilai-nilai karakter yang terkandung didalam materi kinematika gerak lurus adalah mensyukuri ciptaan Tuhan (religius), bekerjasama yang mampu menghasilkan suatu perubahan dalam hidup dan sebagainya.

Melalui penelitian dengan modul ini diharapkan akan diketahui beberapa hal seperti : a. keefektifan modul fisika berbasis karakter dengan pendekatan STM, b. peningkatan kualitas pembelajaran fisika, c. . respon siswa kelas X Madrasah Aliyah Darul Ma'arif Numbay Jayapura dari penerapan modul fisika berbasis karakter dengan pendekatan STM pokok bahasan kinematika gerak lurus, dan $d$. Menghasilkan modul fisika berbasis karakter dengan pendekatan STM pada pokok bahasan kinematika gerak lurus yang memenuhi kriteria modul layak sebagai bahan ajar di Madrasah Aliyah Darul Ma'arif Numbay Jayapura.

\section{METODE PENELITIAN}

Adapun yang menjadi jenis penelitian ini adalah penelitian pengembangan (research \& development $/ R \& D)$ yang mengikuti tahap-tahap pengembangan model siklus 4-D oleh Thiagarajan dan Sammel. Model ini terdiri dari 4 tahap pengembangan, yaitu Define (pendefinisian), Design (Perencanaan), Develop 
(Pengembangan), dan Disseminate (penyebaran).

Uji coba produk diterapkan pada siswa kelas $\mathrm{X}$ yang di ambil dengan cara random sampling. Pada tahap ini dilakukan pembelajaran dan observasi. Setelah pemberian perlakuan selesai, maka siswa di treatment untuk mengetahui ketercapaian hasil belajar siswa.

\section{Uji Coba Skala Kecil}

Uji coba telah dilaksanakan di Madrasah Aliyah Darul Ma'arif Numbay Jayapura. Subjek uji coba adalah siswa kelas X Madrasah Aliyah Darul Ma'arif Numbay Jayapura. Kelompok kecil ini berjumlah 6 responden siswa kelas $\mathrm{X}$ yang di pilih secara acak.

\section{Uji Coba Skala Luas}

Uji coba luas dilakukan pada 2 kelas sampel yaitu kelas $\mathrm{X}_{1}$ dan kelas $\mathrm{X}_{2}$ di Madrasah Aliyah Darul Ma'arif Numbay Jayapura. Pengujian bahan ajar modul yang dikembangkan menggunakan rancangan eksperimen "Nonequivalent Group Pretest-Posttest design”.

Kelas Eksperimen (KE) : $\mathrm{O} \mathrm{X}_{1} \mathrm{O}$

$$
\begin{aligned}
\text { Kelas Kontrol } & (\mathrm{KK}): \mathrm{O}-\mathrm{O}^{\prime} \\
\hline \text { Keterangan : } \mathrm{O}=\text { Pretest } & \\
\mathrm{O}^{\prime}= & \text { Posttest } \\
\mathrm{X}_{1}= & \text { Pembelajaran dengan } \\
& \text { menggunakan modul }
\end{aligned}
$$

\section{Subjek uji coba}

Populasi target adalah adalah siswa kelas X MA Darul Ma'arif Numbay Jayapura semester 1 Tahun ajaran 2015/2016. Subjek uji coba di lapangan menggunakan dua kelas.

\section{Teknik analisis data}

\section{n-Gain Ternormalisasi}

Kategorisasi terhadap nilai
indeks gain yang diperoleh siswa
dilakukan untuk melihat peningkatan penguasaan konsep sebelum dan sesudah pembelajaran digunakan rumus sebagai berikut (Rusnanto, 2008):

$$
\mathrm{n}_{\text {gain }}=\frac{\text { post test }- \text { pre test }}{\text { skor maksimum }- \text { pre test }}
$$

Dalam penelitian ini, persamaan n-Gain digunakan untuk mengukur peningkatan penguasaan konsep siswa. Penentuan kategori nilai indeks n-Gain ini dilakukan pada setiap RPP.

\section{Uji prasyarat analisis}

\section{a. Uji normalitas}

Uji Normalitas digunakan untuk menguji sebaran data memiliki distribusi normal atau tidak. Uji Normalitas dilakukan menggunakan uji Kolmogorov Smirnov pada program SPSS. Menurut Triton (2006), persyaratan data disebut normal jika probabilitas atau $\mathrm{p}>0,05$.

$x^{2}=\sum \frac{\left(f_{0}-f_{\theta}\right)^{2}}{f_{\theta}}$

\section{Ui Homoginitas}


Pengujian prasyarat analisis untuk uji perbedaan (komparatif) yaitu dengan uji Homogenitas. Untuk menguji persamaan antara kelas eksperimen dan kelas kontrol, maka data yang terkumpul harus diuji terlebih dahulu.

$\mathrm{S}^{2}=\frac{\Sigma \mathrm{X}^{2}-\frac{(\Sigma \mathrm{X})^{2}}{\mathrm{n}}}{\mathrm{n}-1}$

Mencari nilai varians terbesar dan varians terkecil dengan rumus:

$\mathrm{F}_{\text {Hitung }}=\frac{\text { Varians Terbesar }}{\text { Varians Terkecil }}$

\section{b. Uji hipotesis}

Uji hipotesis dilakukan untuk mengetahui adanya peningkatan hasil belajar siswa setelah menggunakan Modul fisika berbasis karakter dengan pendekatan STM pada pokok bahasan kinematika gerak lurus dapat diformulasikan sebagai berikut:

$\mathrm{H}_{0}$ : Tidak terdapat peningkatan hasil belajar siswa kelas X Madrasah Aliyah Darul Ma'arif Numbay Jayapura setelah menggunakan modul fisika berbasis karakter dengan pendekatan STM pada materi kinematika gerak lurus.

Ha : Terdapat peningkatan hasil belajar siswa kelas X Madrasah Aliyah Darul Ma'arif Numbay Jayapuar setelah menggunakan modul fisika berbasis karakter dengan pendekatan STM pada pokok kinematika gerak lurus.
Uji hipotesis menggunakan analisis komparasi (analyze Compare Means) dengan One Way Anova untuk mengetahui ada perbedaan rata-rata tes pada kelas control yang diajarkan dengan kelas eksperimen yang menggunakan Modul berbasis karakter. Uji asumsi dasar yaitu homogenitas dengan menggunakan SPSS, jika sig sig $>0,05$, maka $\mathrm{H}_{0}$ diterima. Akan tetapi apabila sig< 0,05; maka $\mathrm{H}_{0}$ ditolak.

\section{HASIL DAN PEMBAHASAN}

\subsection{Efektivitas Modul Berbasis Karakter Dengan Pendekatan STM Pokok Bahasan Kinematika Gerak Lurus Siswa Kelas X Di Madrasah Aliyah Darul Ma'arif Numbay Jayapura.}

Berdasarkan hasil penelitian pada pembelajaran fisika dengan menggunakan modul fisika berbasis karakter dengan pendekatan STM menunjukkan efektivitas dari segi waktu dan aktivitas belajar. Pada kelas eksperimen terlihat efektivitas waktu yang sangat baik daripada pembelajaran di kelas kontrol yang memerlukan waktu lebih banyak. Proses pembelajaran di kelas eksperimen terlaksana dengan tepat waktu sesuai dengan tujuan pembelajaran yang direncanakan, hal ini dikarenakan siswa telah mempelajari materi secara mandiri. Hal ini sesuai dengan penelitian Agung Wicaksono (2009) bahwa "efektivitas berarti ketercapaian atau 
keberhasilan suatu tujuan sesuai dengan rencana dan kebutuhan yang diperlukan, baik dalam penggunaan data, sarana maupun waktunya". Dengan demikian dapat disimpulkan bahwa pembelajaran dikatakan efektif bila kegiatan tersebut dapat diselesaikan pada waktu yang tepat dan mencapai tujuan yang diinginkan.

Hasil belajar kognitif siswa juga digunakan untuk mengetahui keefektivitas produk. Hasil belajar siswa diperoleh dari gabungan antara nilai pretest dan posttest. Diketahui bahwa pembelajaran menggunakan modul fisika berbasis karakter dengan pendekatan STM menunjukkan hasil positif. Hal tersebut diperoleh dari jumlah siswa yang tuntas sebesar 75,9 \% siswa. Dari hasil respon siswa menyatakan bahwa $87 \%$ siswa lebih menyukai pembelajaran fisika dengan menggunakan modul fisika berbasis karakter dengan pendekatan STM pada materi kinematika gerak lurus. Respon siswa tersebut membuktikan bahwa modul fisika yang dikembangkan efektif digunakan untuk siswa kelas $\mathrm{X}$ Madrasah Aliyah Darul Ma'arif Numbay Jayapura. Berdasarkan hasil belajar tersebut, dapat diketahui bahwa pembelajaran menggunakan modul fisika berbasis karakter dengan pendekatan STM lebih efektif dari pada menggunakan bahan ajar lain dan hasil belajar siswa lebih baik dari kelas yang tidak menggunakan modul. Hal itu sesuai dengan penelitian yang dilakukan oleh Rodiah (2010) bahwa terdapat perbedaan prestasi belajar antara siswa yang menggunakan modul fisika dan siswa yang menggunakan buku teks fisika.

Hasil perhitungan gain ternomalisasi pada kelas eksperimen adalah 0,435 berada dalam kategori sedang. Data ini menunjukkan bahwa melalui ujicoba pembelajaran menggunakan modul berbasis karakter dengan pendekatan STM cukup meningkatkan hasil belajar kognitif siswa, sedangkan pada kelas kontrol mempunyai nilai gain 0,271 berada dalam kategori rendah. Dari hasil penelitian ini terdapat perbedaan antara respon siswa yang mempunyai persentase dengan kriteria sangat baik dengan hasil rata-rata nilai kognif siswa yang hanya mencapai kriteria cukup. Hal ini disadari peneliti karena adanya faktor-faktor yang mempengaruhi karakteristik siswa di Madrasah Aliyah Darul Ma'arif Numbay Jayapura antara lain sebagian besar siswa yang belajar di Madrasah Aliyah Darul Ma'arif Numbay Jayapura adalah siswa yang lebih tertarik dengan ilmu agama.

\subsection{Peningkatan Kualitas Pembelajaran Fisika Dari Pegembangan Modul Fisika Berbasis Karakter Dengan Pendekatan STM Pada Pokok}


Bahasan Kinematika Gerak Lurus Siswa Kelas X Di Madrasah Aliyah Darul Ma'arif Numbay Jayapura.

Dari hasil penelitian menunjukkan bahwa produk yang merupakan hasil pengembangan lebih efektif untuk meningkatkan kualitas pembelajaran fisika siswa kelas X Madrasah Aliyah Darul Ma'arif Numbay Jayapura. Terdapat perbedaan rata-rata capaian hasil belajar siswa antara kelas eksperimen dengan kelas kontrol. Pada kelas kontrol tidak diberikan perlakuan untuk menggunakan produk pada proses pembelajaran, sedangkan pada kelas eksperimen diberikan perlakuan untuk menggunakan produk pada proses pembelajaran.

Dari hasil perhitungan dengan menggunakan uji Anova diproleh bahwa nilai rata-rata capaian hasil belajar siswa kelas eksperimen 77,53 sedangkan pada kelas kontrol 56,00. Dari data ini menggambarkan bahwa terjadi peningkatan nilai tes akhir pada kelas eksperimen dimana didalamnya diberikan perlakuan menggunakan produk dalam kegiatan pembelajaran fisika, sehingga disimpulkan bahwa penerapan produk efektif untuk meningkatkan kualitas pembelajaran fisika siswa kelas $\mathrm{X}$ Madrasah Aliyah Darul Ma'arif Numbay Jayapura.

$$
\text { Peningkatan }
$$

kualitas

pembelajaran juga terlihat pada proses pembentukan karakter yang dinilai dari mulai terlihatnya indikator karakter yang dilakukan oleh siswa. Dari proses ini dapat diketahui bahwa terjadi peningkatan jumlah siswa yang menunjukkan mulai terlihatnya indikator karakter. Proses pembentukan karakter pada dasarnya memerlukan waktu yang lama, sebagaimana dikatakan oleh Nugroho (2011) bahwa pembentukan karakter terjadi dengan beberapa tahapan untuk mengubah karakter personal yakni dimulai dari ketidakpuasan, dilanjutkan dengan memiliki visi yang logis dan rasional, berani mengambil resiko, bertanggungjawab hingga sampai pada tahap konsisten. Pada tahap konsisten sudah dapat dikatakan adanya perubahan karakter pada diri seseorang. Hal ini tentu tidak mudah mengingat berbagai tantangan yang dihadapi siswa setiap harinya. Oleh karena itu dalam waktu beberapa kali pertemuan dalam pembelajaran, karakter siswa sulit diketahui tingkat konsistensinya. Pengintegrasian pendidikan karakter dalam proses pembelajaran dilakukan dengan pengenalan nilai-nilai, memfasilitasi diperolehnya kesadaran akan pentingnya nilai-nilai, dan 
penginternalisasian nilai-nilai ke dalam tingkah laku sehari-hari.

Diharapkan kegiatan pembelajaran dapat menjadikan siswa menguasai kompetensi fisika secara utuh yaitu tidak hanya menguasai pengetahuan tetapi juga menyadari/peduli, dan menginternalisasi nilai-nilai dan perilaku dalam kehidupan sehari-hari, sehingga menjadi karakter siswa.

Dari hasil penelitian karakter yang ditunjukkan lebih dominan terlihat adalah karakter religius $(100 \%)$ dan sifat rasa ingn tahu (90\%). Pada peningkatan karakter ini menunjukkan bahwa peneliti harus mengenal lebih dalam pribadi siswa.

\subsection{Respon Siswa Kelas X Madrasah} Aliyah Darul Ma'arif Numbay Jayapura Terhadap Pengembangan Modul Fisika Berbasis Karakter Dengan Pendekatan STM Pokok Bahasan Kinematika Gerak Lurus.

Tahap uji coba skala terbatas yaitu

uji coba pengembangan modul pada sampel yang terbatas atau skala kecil. Uji skala terbatas dilakukan di kelas $\mathrm{X}$ sebanyak 6 siswa. Dalam tahapan ini modul yang digunakan adalah modul yang telah diperbaiki kekuranganya sesuai hasil validasi ahli dan saran yang diberikan ahli materi dan ahli media pembelajaran. Hasil uji coba skala terbatas meliputi hasil tanggapan siswa tentang modul yang dikembangkan.
Tanggapan siswa yang diberikan pada uji coba skala terbatas dan skala luas secara keseluruhan semua aspek mendapat tanggapan positif dengan skor $83 \%$ pada uji skala terbatas dan $83 \%$ pada uji skala luas termasuk dalam kriteria "sangat baik".

Tanggapan positif yang diberikan siswa terhadap modul fisika dikarenakan produk modul yang dihasilkan memiliki beberapa keunggulan yaitu sifatnya yang menarik, sajian materi gerak yang mudah dipahami oleh siswa melalui bahasa yang sederhana dan gambar yang proporsional dapat mengarahkan siswa memahami uraian materi. Persentase pada seluruh item angket baik pada uji skala terbatas maupun uji skala luas diakumulasi dan diambil rata-ratanya terjadi peningkatan rata-rata dari $83 \%$ menjadi $91 \%$. Hasil tersebut menginterpretasikan revisi dan validasi yang dilakukan setelah uji coba skala terbatas dinilai sangat berperan untuk meningkatkan persentase kelayakan modul.

Modul juga mampu meningkatkan minat belajar karena pengguna warna yang bervariasi dan desain yang menarik. Meningkatnya minat dan motivasi siswa dalam belajar akan berdampak pada meningkatnya hasil belajar siswa, hal ini dapat dilihat dari persentase siswa yang mencapai $76 \%$ yang tuntas KKM. 


\subsection{Hasil Pengembangan Modul fisika Berbasis Karakter Dengan Pendekatan STM Materi Kinematika Gerak Lurus Sebagai Bahan Ajar Di Madrasah Aliyah Darul Ma'arif Numbay Jayapura. Penelitian pengembangan}

penelitian ini telah melalui beberapa tahapan yaitu mulai dari tahap pendefinisian, perencanaan, pengembangan dan penyebaran. Peneliti mendesain pengembangan modul fisika agar siswa mampu belajar mandiri. Modul yang dikembangkan adalah modul fisika berbasis karakter dengan pendekatan STM. Pendekatan ini dipilih peneliti karena pendekatan ini langsung berkaitan ilmu yang datang dari kehidupan sehari-hari, karena ilmu fisika merupakan salah satu tonggak kemajuan teknologi. Selain itu kelebihan dari pendekatan STM adalah siswa dapat melihat relevansi teknologi yang digunakan saat ini dengan konsep-konsep dan prinsip sains yang sedang mereka pelajari.

Hasil analisis penilaian validator materi maupun media yang menunjukkan persentase $82 \%$ yang berarti bahwa modul fsika berbasis karakter dengan pendekatan STM yang dikembangkan telah memenuhi syarat-syarat penyusunan modul pembelajaran yang baik, diantaranya menyusun kerangka modul dengan merumuskan tujuan pembelajaran, kesesuaian isi pada modul pembelajaran, kejelasan petunjuk yang ada dalam modul pembelajaran, kesesuaian format pada modul pembelajaran, keserasian warna, tampilan gambar dan tulisan pada materi sehingga memudahkan siswa memahami materi kinematika gerak lurus.

Selain itu kriteria kelayakan modul sebagai bahan ajar juga di tunjukkan dengan respon siswa kelas X Madrasah Aliyah Darul Ma'arif yang sangat baik yaitu sebesar $87 \%$ dan terdapat peningkatan hasil belajar siswa sebesar $76 \%$ yang tuntas mencapai nilai KKM.

\section{SIMPULAN DAN SARAN}

\subsection{Simpulan}

Dari hasil penelitian dapat disimpulkan bahwa:

1.Keefektivitas pada pembelajaran fisika dengan menggunakan modul fisika berbasis karakter dengan pendekatan STM menunjukkan efektif dari segi waktu dan aktivitas belajar yang lebih baik

2.Modul fisika berbasis karakter dengan pendekatan STM pada pokok bahasan kinematika gerak lurus dapat meningkatkan kualitas pembelajaran siswa, hal ini ditunjukkan dengan terjadinya peningkatan jumlah siswa kelas X Madrasah Aliyah Darul Ma'arif Numbay Jayapura yang 
menunjukkan terlihatnya indikator karakter dan peningkatan hasil belajar siswa

3. Modul berbasis karakter dengan pendekatan STM ini memperoleh respon positif selama pembelajaran fisika berlangsung..

4. Modul fisika berbasis karakter dengan pendekatan STM materi kinematika gerak lurus baik untuk dikembangkan dan digunakan sebagai bahan ajar dalam kegiatan pembelajaran fisika siswa kelas X di Madrasah Aliyah Darul Ma'arif Numbay Jayapura.

\subsection{Saran}

Berdasarkan kesimpulan yang diperoleh dari penelitian ini, penulis menyarankan hal-hal sebagai berikut :

1. Untuk meningkatkan kualitas pembelajaran fisika di sekolah diperlukan kerja keras guru fisika untuk berinovasi melakukan mediamedia pembelajaran sebagai salah satu terwujudnya iklim belajar fisika yang menyenangkan.

2. Produk dikembangkan ini dapat dikembangkan kembali khususnya guru fisika sebagai upaya untuk meningkatkan capaian hasil belajar fisika.

\section{DAFTAR PUSTAKA}

Arikunto, Suharsimi. 2010. Prosedur Penelitian. Jakarta: Rineka Cipta
Nisak, K \& Susasntini, E. 2013. Pengembangan Perangkat Pembelajaran IPA Terpadu Tipe Connected pada Materi Pokok Sistem Ekskresi untuk Kelas IX SMP. Jurnal Pendidikan Sains e-Pensa, 1(1).

Ningsih, W. D. 2012. Pengaruh Penggunaan Modul Melakukan Pekerjaan dengan Mesin Frais Terhadap Prestasi Belajar Siswa Kelas XI pada Mata Pelajaran Pemesinan di SMK $N 2$ Klaten. Skripsi. Prodi Teknik Mesin Fakultas Teknik UNY

Rusnanto. 2008. Metode Penelitian. http://a-

research.upi.edu/s_bio_060878

chapter3, diakses 16 Desember 2015.

Nugroho, Widyo Sulasdi. 2011. "Integrasi Pendidikan Berkarakter dalam Kurikulum MIPA dan Pendidikan MIPA". Seminar Nasional FMIPA UNP.Padang: 19 November 2011.

Poedjiadi, A. 2010. Sains Teknologi Masyarakat, Model Pembelajaran Kontekstual Brmuatan Nilai. Bandung: Remaja Rosdakarya.

Rodiah. 2010. Efektivitas Implementasi Modul IPA Terpadu Melalui Pembelajaran Model Integrasi Terhadap Prestasi Belajar Siswa Kelas VII-C SMP Negeri 2 TuguTrenggalek. Skripsi. Prodi Pendidikan Fisika Jurusan Fisika FMIPA Universitas Negeri Malang.

Sudjana. (2005). Metode Statistika. Bandung: Rosdakarya

Sugiyono. 2012. Statistika Untuk Penelitian. Bandung: Alfabeta. 